Prepared in cooperation with the City of Kansas City, Missouri, Water Services Department

\title{
Water Quality in the Blue River Basin, Kansas City Metropolitan Area, Missouri and Kansas, July 1998 to October 2004
}

\author{
—Donald H. Wilkison, Daniel J. Armstrong, Richard D. Norman, Barry C. Polton, Edward T. Furlong, and Steven D. Zaugg
}

\section{Introduction}

Stream-water quality in the Blue River Basin is influenced by a variety of factors including urbanization, point and nonpoint source pollution, physical stream conditions, and complex water-quality processes. The Blue River Basin encompasses 280 square miles and roughly onehalf of the Kansas City metropolitan area south of the Missouri River. Fifty-four percent of the basin is located in Kansas and 46 percent is located in Missouri. The U.S. Geological Survey (USGS), in cooperation with the City of Kansas City, Missouri, Water Services Department, collected water-quality data from July 1998 to October 2004 to provide an assessment of the chemical, bacteriological, and biological conditions of basin streams, identify sources of selected constituents, and provide an understanding of factors affecting water quality. The results of these studies are described in Wilkison and others $(2002 ; 2005 ; 2006)$, and are summarized in this fact sheet.

Kansas City, Missouri, is 1 of approximately 750 municipalities in the United States with a combined sewer system. Such systems carry sanitary wastewater and stormwater runoff and function differently during dry and wet weather conditions. In dry weather, combined systems convey sewage from homes, businesses, and industry to a wastewater-treatment plant

(WWTP). After treatment, the water is discharged to a receiving stream in accordance with applicable water-quality standards. During wet weather, runoff from streets, rooftops, parking lots, and lawns enters the combined system and is delivered to the WWTP for treatment and discharge. However, if runoff and sewage volumes exceed the pipe or WWTP capacity then excess flow (a mixture of stormwater and untreated sewage) is diverted and discharged to receiving streams, events referred to as combined sewer overflows (CSOs). Roughly 90 percent of the CSO outfall points in Kansas City, Missouri, are located within the Blue River Basin.

Communities with combined sewer systems are required under federal and state regulations to develop a plan to control overflows and to monitor their effects on receiving waters. Control plans include analysis of current water-quality conditions based on a watershed perspective and characterization of other pollutant sources that might inhibit the attainment of applicable water-quality standards (U.S. Environmental Protection Agency, 1999). Laboratory and hydrologic analysis of Blue River Basin stream samples collected during base flow (defined as streamflow unaffected by storm runoff) and stormflow events were undertaken to understand the effects of wastewater on urban receiving streams and to support development of a control plan. Analyses included physical properties, nutrients, selected organic wastewater compounds (OWCs), selected prescription and overthe-counter pharmaceutical compounds,
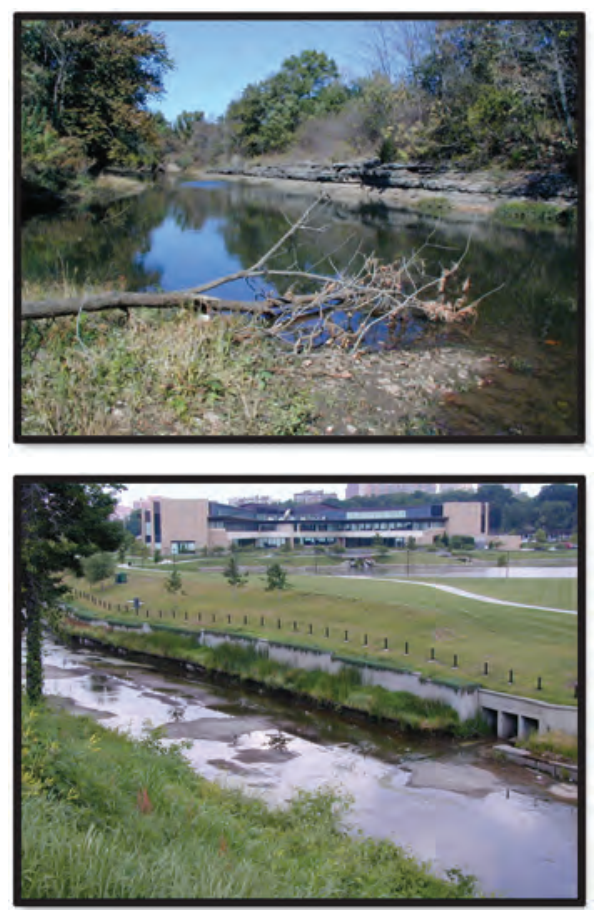

Selected stream reaches of the Blue River Basin. (Top left, Blue River downstream from site 2 [fig. 1]; top right, Indian Creek upstream from site 6; bottom left, Brush Creek downstream from site 11; bottom right, Blue River upstream from site 13.) quality profiles were determined for selected

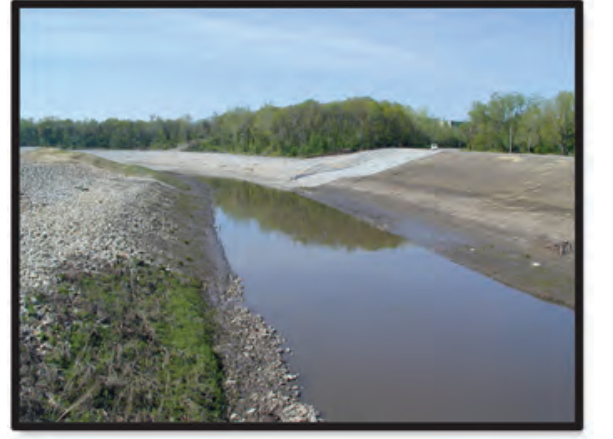

\section{Escherichia coli (E. coli) and fecal} coliform bacteria, and benthic macroinvertebrates (fig. 1). Selected base-flow E. coli samples were analyzed for host source using genotypic, geographic-specific, librarybased methods (Dombek and others, 2000; Carson and others, 2003). Vertical waterimpounded reaches of Brush Creek. (fig. 2).

Sample locations were determined based on a variety of factors including proximity to tributaries, the combined sewer system area, and WWTPs (fig. 1). Six sites on the main stem of the Blue River (sites 1, 2, 7, 8, 13, and 14), four sites on the tributary Brush Creek (sites 9 to 12), and three sites on the tributary Indian Creek (sites 3, 4, and 6) were sampled. Two stream sites, one in the basin (site 5, Tomahawk Creek) and one outside of the basin (site 19, South Grand River) were sampled as controls for aquatic-biota measurements. Data from four WWTPs (sites 15 to 18) located in the basin also were analyzed.

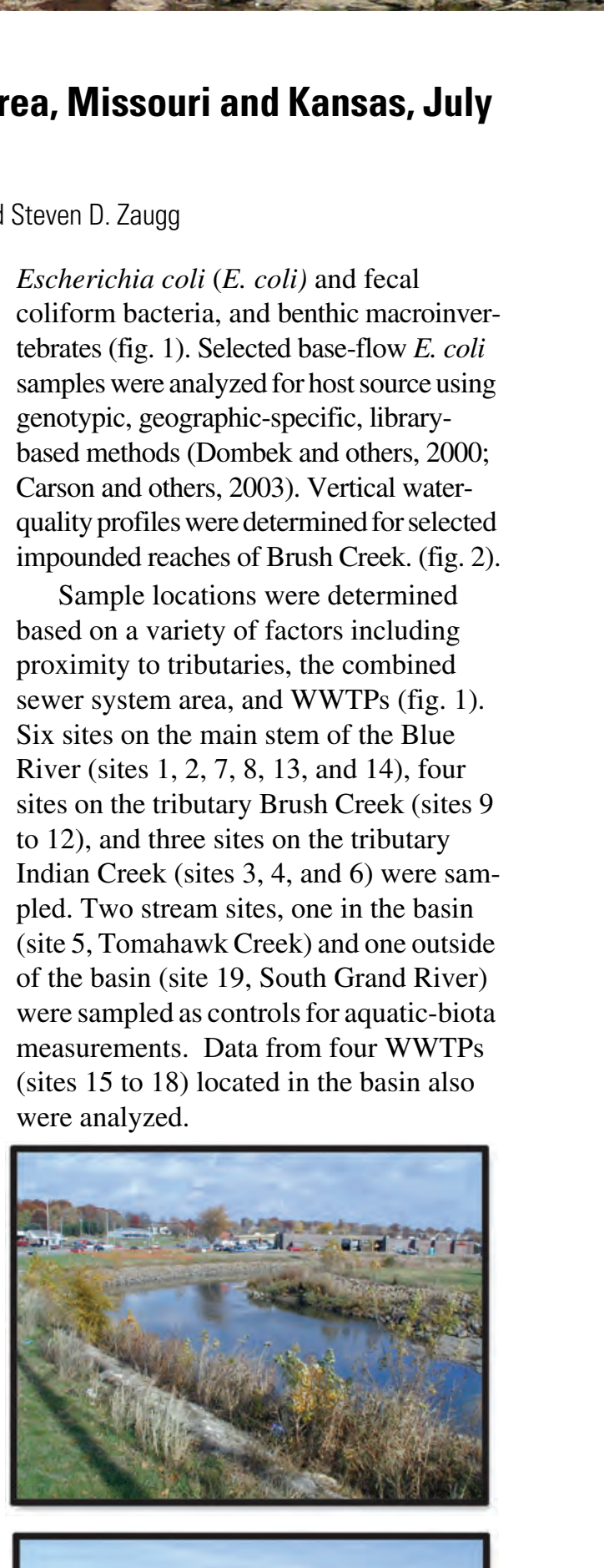




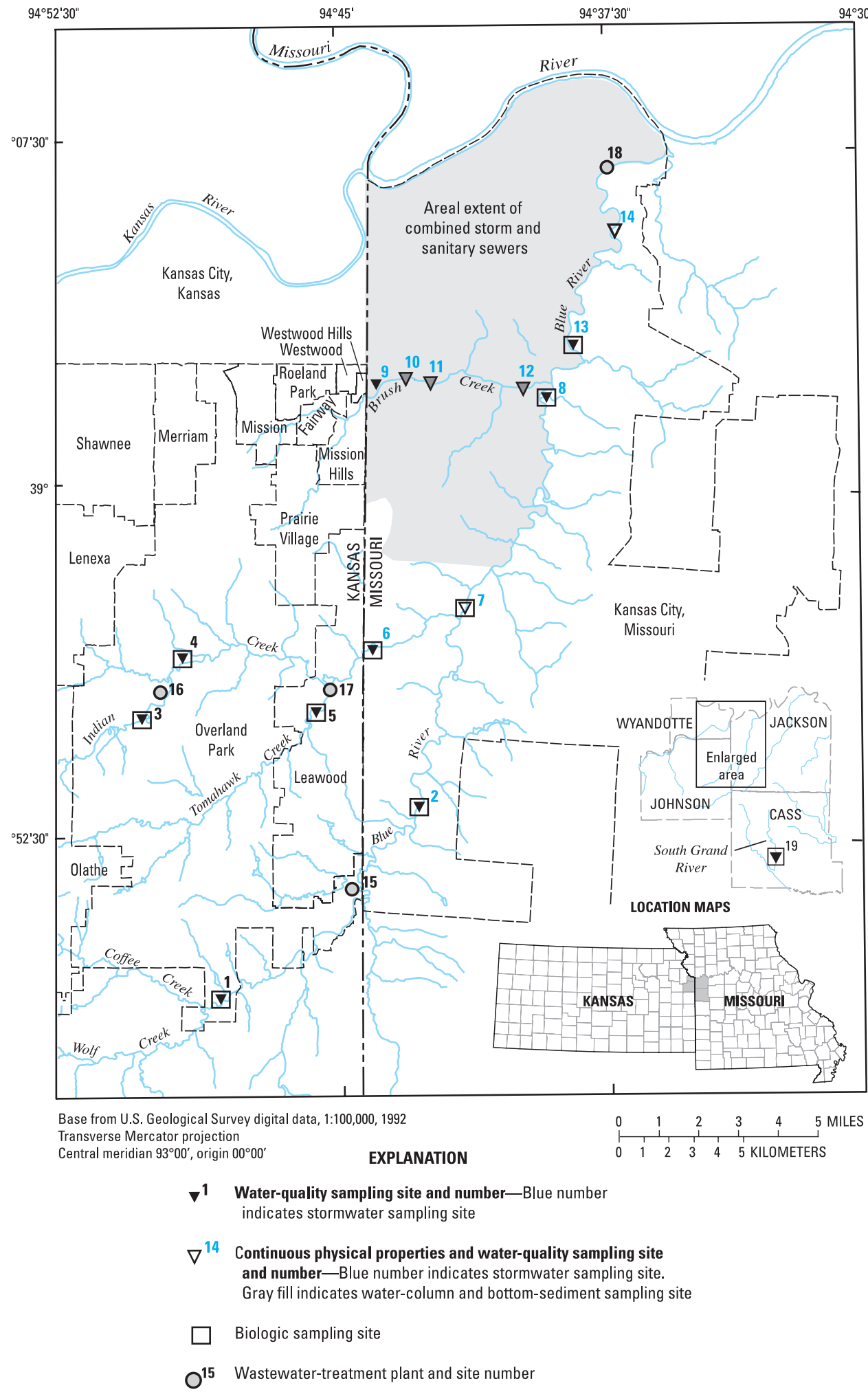

Figure 1. Location of study area, sampling sites, wastewater-treatment plants, and area of combined storm and santiary sewers.

\section{Major Factors Affecting Stream- Water Quality}

The combination of numerous over-lapping, urban-related factors has adversely affected water quality and the ecological condition of several stream reaches in the Blue River Basin. Urbanization and floodcontrol projects have resulted in substantial loss of riparian vegetation, degraded stream habitat through stream channelization and streambank armoring, and resulted in extensive loss of native pool and riffle sequences, and altered flow regimes. Urban non-pointsource runoff contributed a substantial part of the pollutant load in the basin. In areas served by a combined sewer system and WWTPs, discharges of treated and untreated wastewater additionally contributed nutrients, OWCs, and pharmaceuticals to streams. Nutrient enrichment was common at many stream sites with concentrations greater than expected background, non-urban concentrations (Smith and others, 2003). Deleterious water-quality effects were most pronounced in lower Indian Creek (below site 4), the lower and middle reaches of the Blue River (below site 7), and lower Brush Creek (below site 11).

Although there was some daily and seasonal variability, WWTPs provided the dominant source of streamflow, nutrients, and OWCs and pharmaceutical compounds to the middle and lower Indian Creek and the Blue River during base flow. Downstream from WWTPs, effluent can comprise greater than 95 percent of base flow. Only a small part of effluent nutrients were removed by in-stream processes, an indication that such contributions frequently exceed the ecological assimilation capacity of many reaches. During storms, the predominant source of nutrients shifted from point sources to non-point sources. Examples of non-point sources that may contribute nutrients to streams include runoff from fields, parks, golf courses, lawns, and impervious surfaces; storm sewers; compromised sewer lines; and ground- and surface-water interactions with these sources. As flows increased, the concentration of dissolved nutrients decreased (figs. 3a and 3b) while concentrations of suspended nutrients, suspended sediment, and fecal indicator bacteria increased (fig. $3 \mathrm{c}$ to $3 \mathrm{f}$ ). Suspended sediment and fecal indicator bacteria loads (concentration times flow) 


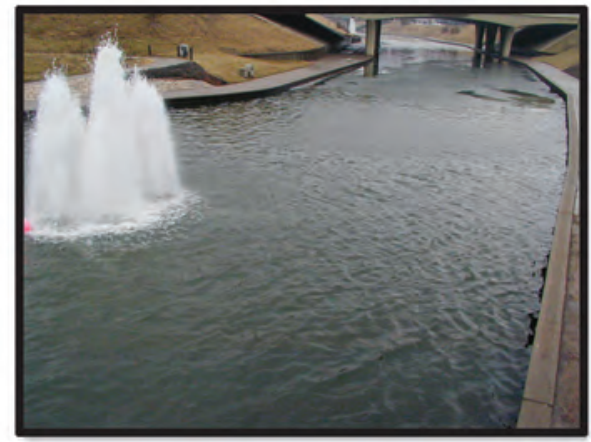

Upper impoundment (Plaza pool) above site 10 , February 2001.

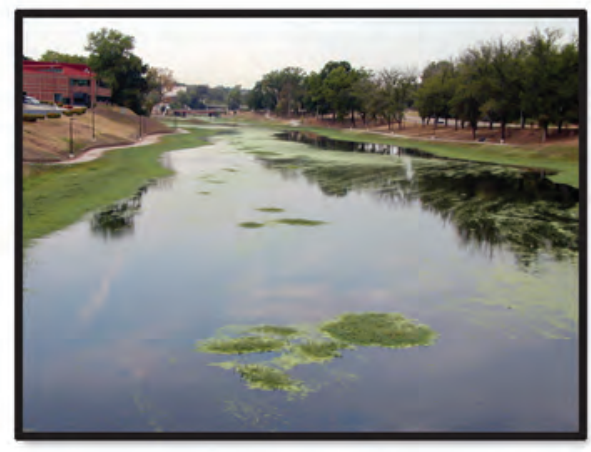

Lower impoundment (Lake of the Enshriners) near site 12, August 2003.

Figure 2. Views of impounded reaches of Brush Creek. increased substantially over those measured in base-flow samples at all stream sites.

In Brush Creek, wet weather events provided the dominant source of nutrients. Storm-event nutrient loads, a combination of non-point and CSO sources, were 200 to 300 times greater than base-flow loads. Because of hydrologic alterations to Brush Creek, particulate nutrients were trapped in impounded reaches - a process that facilitated algal growth in these reaches.

\section{Nutrients}

Total nitrogen and total phosphorus loads and yields (load divided by drainage area) were estimated at four basin sites to allow comparison between sites and to those estimated at sites outside of the basin (fig. 4). Approximately 60 percent of the total nitrogen and total phosphorus in the middle and lower Blue River originated from Indian Creek, smaller amounts from the upper Blue River (from 16 to 28 percent), and less than 5 percent from Brush Creek. Nutrient yields from the lower Indian Creek (site 6) and the middle Blue River (site 7) were significantly greater than yields from the upper Blue River (site 2), lower Brush Creek (site 11), and sites outside the basin (fig. 4). Total nitrogen and total phosphorus yields from the upper Blue River and lower Brush Creek were not significantly different from one another.

\section{Organic Wastewater and Pharma- ceutical Compounds}

Organic wastewater compounds analyzed included a suite of organic chemicals common to household, industrial, and personal care products, including, but not limited to, detergent by-products, disinfectants, antimicrobials, plasticizers, musk, and fragrance compounds. Pharmaceutical compounds included analgesics (acetaminophen and ibuprofen), an anti-convulsant (carbemazepine), antibiotics (sulfamethoxazole and trimethoprim), cardiac and anti-clotting medications (dehydronifedipine, diltiazem, and warfarin), a cholesterol-regulator (gemfibrozil), a narcotic (codeine), and stimulants (caffeine and cotinine, a metabolite of nicotine).

At sites on Indian Creek and the Blue River, organic wastewater and pharma-
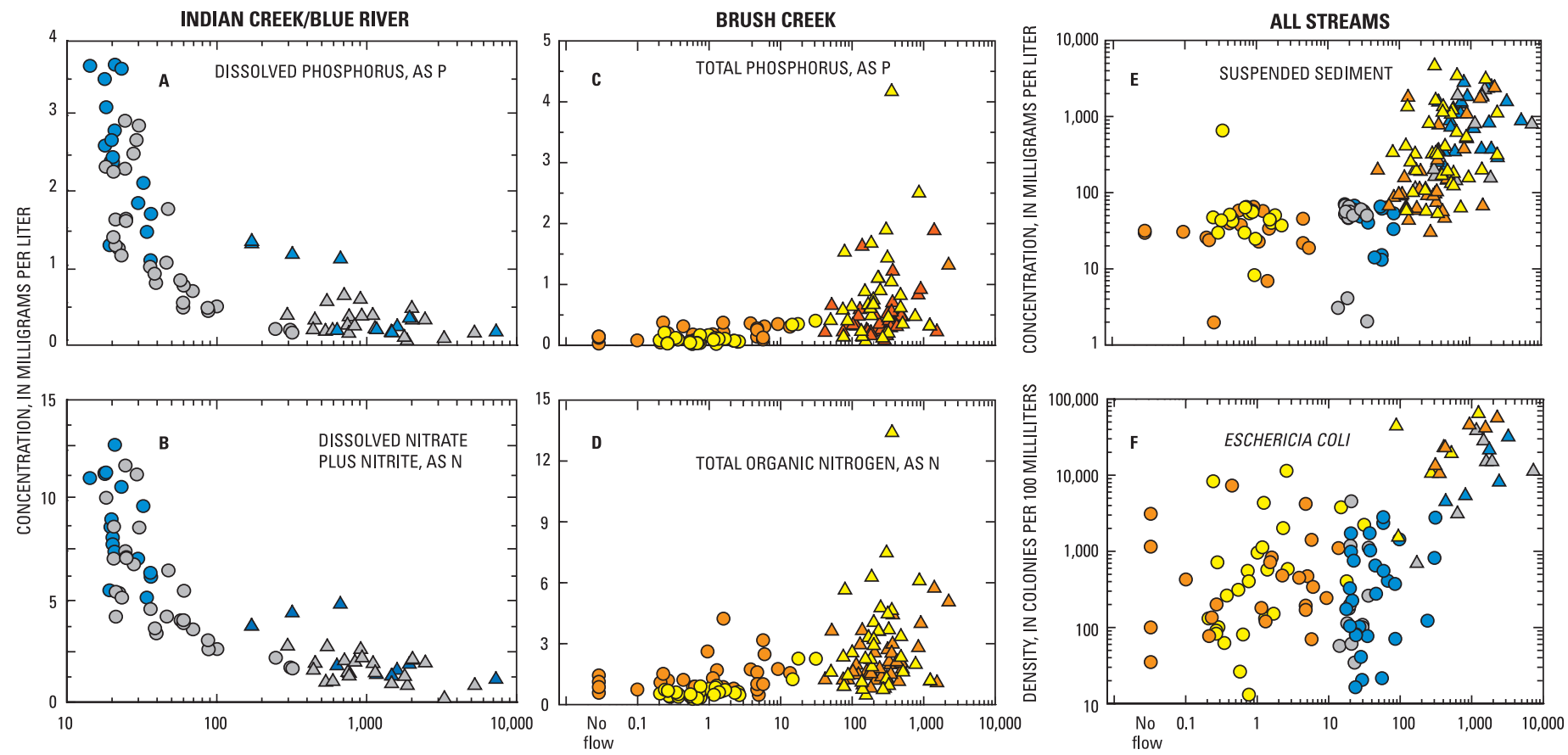

DISCHARGE, IN CUBIC FEET PER SECOND

\section{EXPLANATION}

Site $\mathbf{6}$ (Indian Creek)
Base flow
$\triangle$ Stormflow

$\begin{array}{cc}\text { Site } \mathbf{7} \text { (Blue River) } & \text { Site } \mathbf{9} \text { (Brush Creek) } \\ \circ \text { Base flow } & \bigcirc \text { Base flow } \\ \Delta \text { Stormflow } & \Delta \text { Stormflow }\end{array}$

Site 11 (Brush Creek)

- Base flow

$\triangle$ Stormflow

Figure 3. Concentrations of selected water-quality constituents in relation to discharge. 
ESTIMATED YIELD IN THE BLUE RIVER BASIN BLUE RIVER BASIN

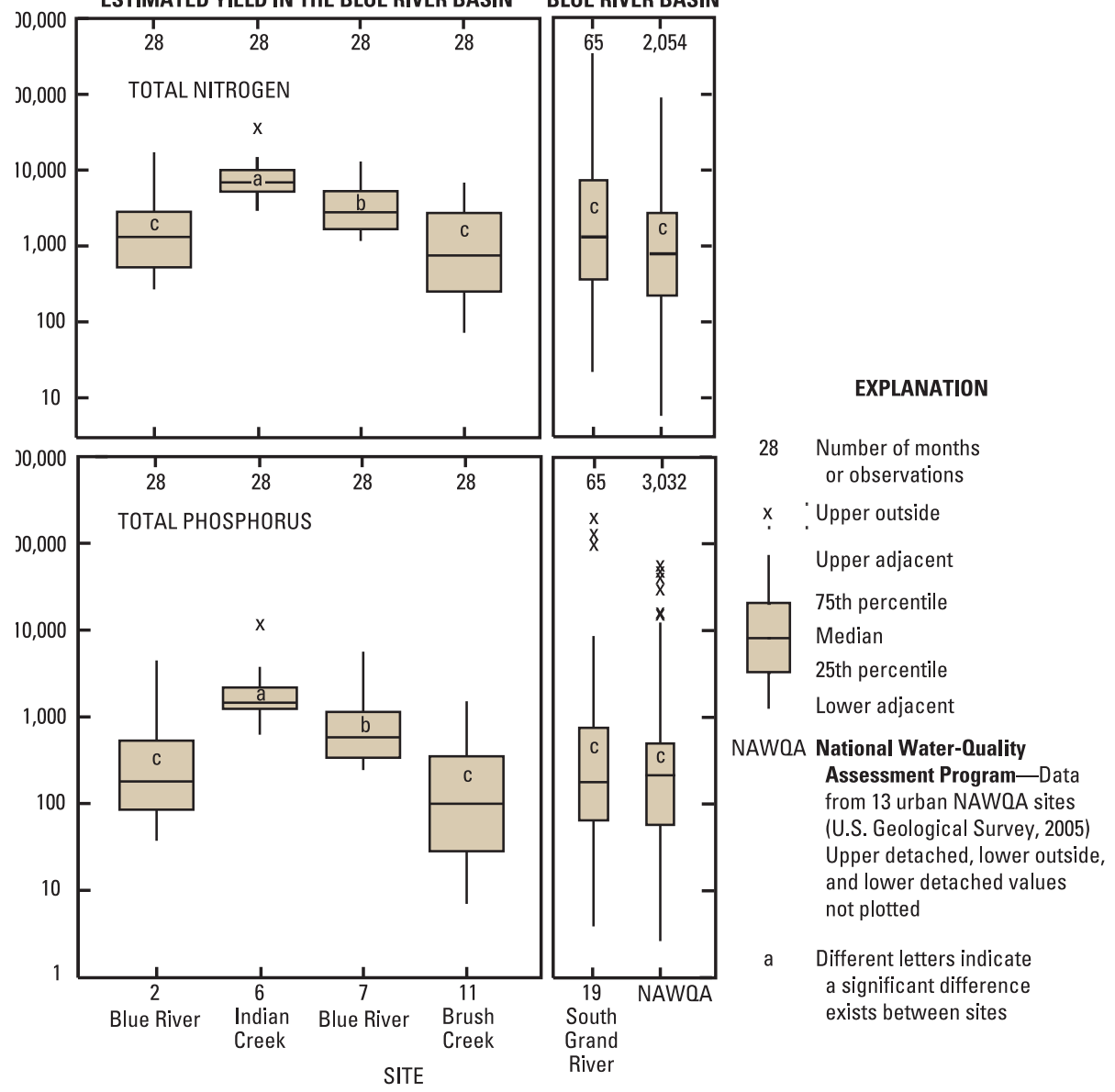

Figure 4. Estimated yields of total nitrogen and total phosphorus at selected sites in the Blue River Basin from July 2002 through September 2004.

ceutical compounds were largely attributable to WWTP discharges during base flow (figs. 5 and 6). Two classes of OWCs, defined operationally as detergents (consisting of surfactants and byproducts) and sterols (consisting of plant and animal sources such as cholesterol and coprostanol) constituted the majority of OWCs. Over-the-counter medications constituted the bulk of the pharmaceuticals. Concentrations of most OWCs and pharmaceuticals decreased in stormflow samples except for two classes of OWCs-pesticides and residues from hydrocarbon combustion and petroleum products-which increased during storms indicating substantial non-point source contributions of these compounds during runoff events.

On Brush Creek, sources of OWCs and pharmaceuticals were largely attributable to a combination of wet weather non-point and CSO sources as evidenced by general increases in contaminant concentrations with flow. Increased OWC concentrations and streamflow resulted in OWC storm loads several orders of magnitude greater than in base flows (fig. 5). Frequent detections of wastewater compounds at site 9 (upstream from most CSOs) during base flow and stormflows indicated that other factors may be as important as CSOs in the occurrence of these compounds in Brush Creek.

\section{Bacteria Sources}

Bacteria in streams were largely the result of non-point source contributions during storms. Fecal coliform densities in Brush Creek were greatest during the period May through September of each year and correlated strongly with periods of precipitation greater than 0.5 inch. Based on genetic-source tracking in baseflow samples, average presumptive source of in-stream $E$. coli bacteria from human sources ranged from 28 to 42 percent, dogs ranged from 26 to 32 percent, geese contributed between 8 and 19 percent, and 18 to 28 percent were from unknown sources. Bacteria sources and relative percentages changed temporally and likely changed in response to flow conditions.

\section{Brush Creek Impoundments}

Impounded reaches of Brush Creek alter stream hydrology and affect water quality. Vertical water-quality changes were greatest in the larger, deeper, downstream pool (known as Lake of the Enshriners) near site 12. Unlike the smaller, shallower, upper pools, Lake of the Enshriners was prone to thermal stratification. Algal blooms occurred during warm, sunny conditions (fig. 3) because Brush Creek was not nutrient limited. Biogeochemical activity in bottom sediments sometimes reduced and removed nitrogen from the system. During wet periods, precipitation events frequently caused replacement of impounded water which had the benefit of pushing out algae matter or stagnant, anoxic water. However, stormwater brought sediment, organic matter, and nutrients into impoundments where it collected. Biochemical oxygen demand often reduced impoundment oxygen concentrations for several days following storms. These processes, coupled with less mixing, resulted in mean daily dissolved oxygen concentrations in Brush Creek that were significantly less than values measured in the Blue River and were sometimes less than the minimum standard for full protection of aquatic life (fig. 7). The trophic state, a measure of biological productivity (or nutrient status), of Brush Creek impoundments was similar to other urban lakes in Missouri and ranged from oligotrophic (little productivity) after rainfall events to hypereutrophic (excessive productivity) during extended dry periods.

\section{Macroinvertebrate Community Assessment}

The diversity and abundance of stream fauna measured at upper Blue River sites (sites 1 and 2) consistently scored at, or above, the control site (site 19) indicating that streamwater quality was sufficient to support a diverse biological component in the upper Blue River (fig. 8). Aquatic community integrity declined downstream in the basin in response to increases in several inter-related urbanization factors including declines in vegeta- 


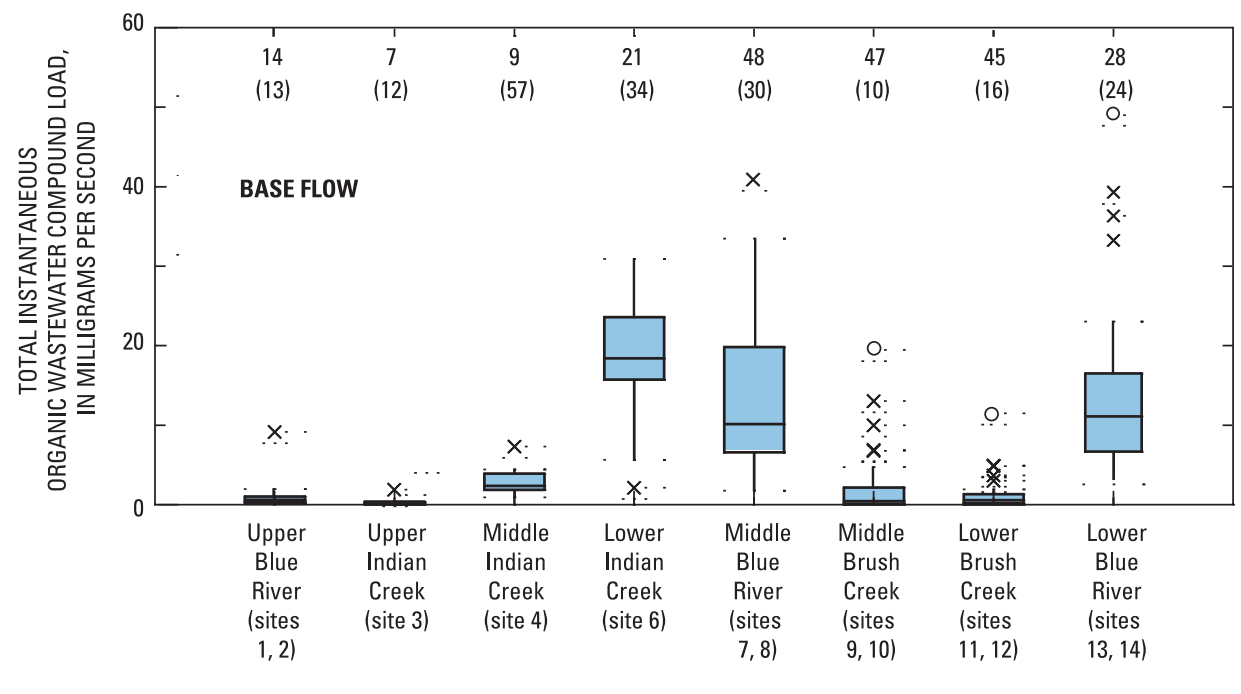

EXPLANATION

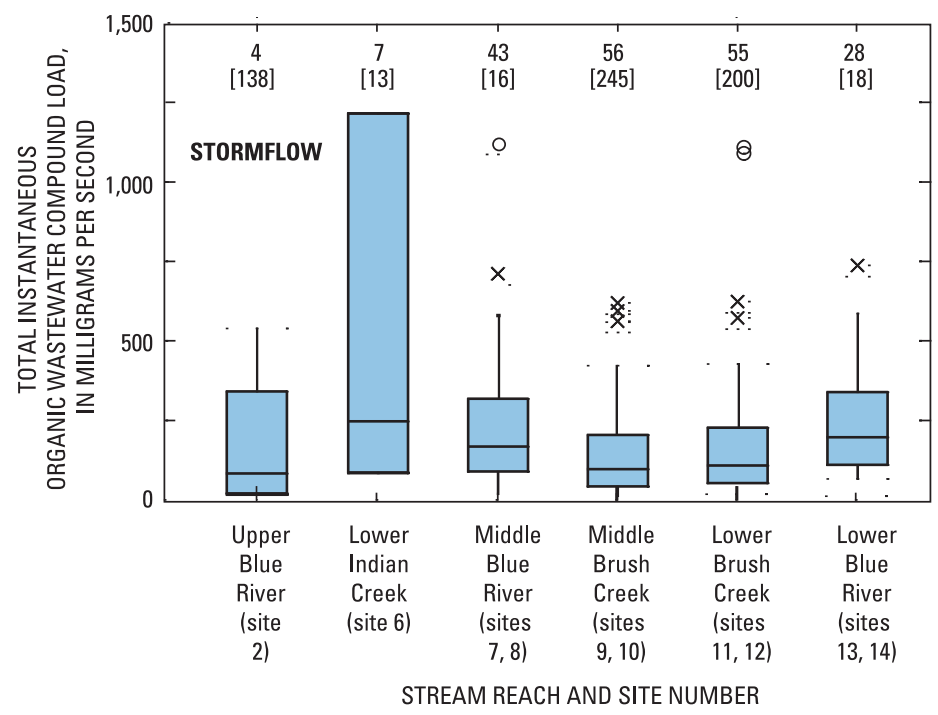

(10) Percentage of total mass of organic wastewater compounds as detergents

[245] Number of times increase over base flow

28 Number of samples

O Upper detached

$\times$ Upper outside

Upper adjacent

75th percentile Median 25th percentile

Lower adjacent

Figure 5. Total instaneous organic wastewater compound load by stream reach in samples collected between August 1998 and September 2004.

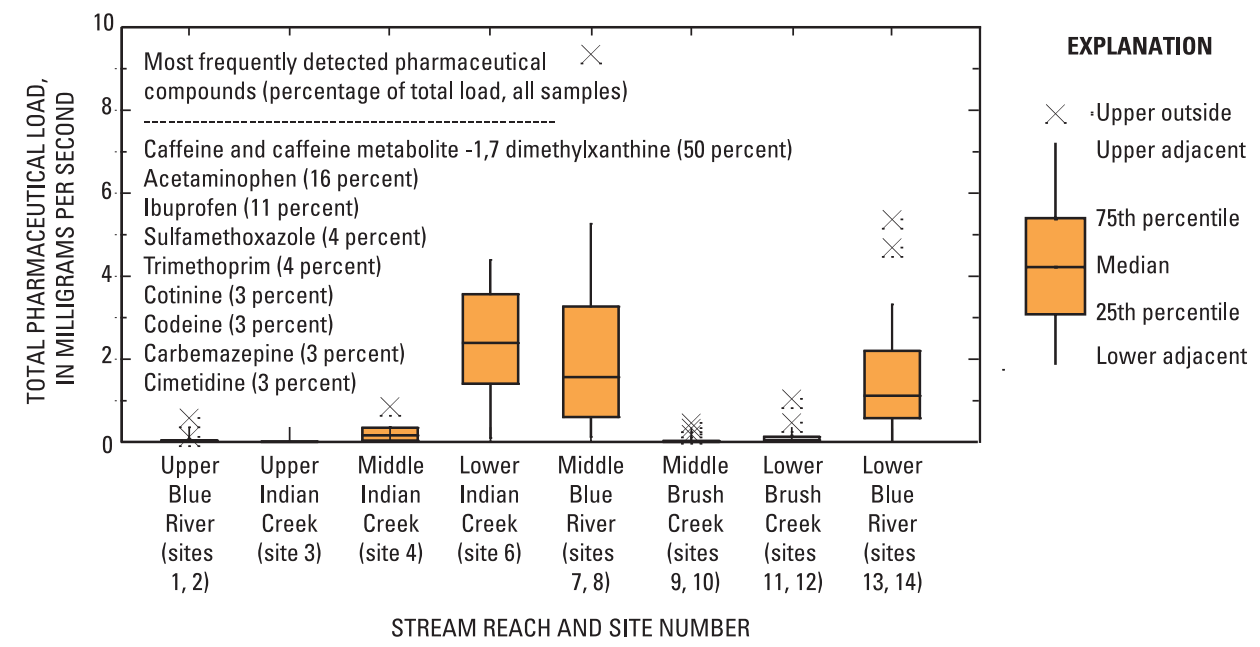

Figure 6. Total pharmaceutical load in base-flow stream samples collected between May 1999 and June 2004, most frequently detected compounds, and percentage of total load.

tive cover, increases in percent impervious cover, increased nutrient enrichment, and increased wastewater inputs.

\section{References}

Carson, A.C., Shear, B.L., Ellersieck, M.R., and Schnell, J.D., 2003, Comparison of ribotyping and repetitive extragenic palindromic-PCR for identification of fecal Escherichia coli from humans and animals: Applied and Environmental Microbiology, v. 3, p. $1,836-1,839$.

Dombek, P.E., Johnson, L.K., Zimmerley, S.T., and Sadowsky, M.J., 2000, Use of repetitive DNA sequences and the PCR to differentiate Escherichia coli isolates from human and animal sources: Applied and Environmental Microbiology, v. 66, p. 2,572-2,577.

Smith, R.A., Alexander, R.B., and Schwartz, G.E., 2003, Natural background concentrations of nutrients in streams and rivers of the coterminous United States: Environmental Science and Technology, v. 37 , no. 14, p. 3,039-3,047.

State of Missouri, 2005, Code of State Regulations, Title 10, Division 20, Chapter 7-Water Quality, 135 p. Accessed May 2006 at URL http:// www.sos.mo.gov/adrules/csr/current/ 10csr/10c20-7a.pdf.

U.S. Environmental Protection Agency, 1999, Combined sewer overflowsGuidance for monitoring and modeling: Washington, D.C., Office of Water, EPA 832-B-99-002, variously paged.

U.S. Geological Survey, 2005, National Water-Quality Assessment Program retrospective database for nutrients in ground and surface water: accessed September 2005 at URL http:// water.usgs.gov/nawqa/nutrients/ dataset/retro.data.sw.

Wilkison, D.H., Armstrong, D.J., and Blevins, D.B., 2002, Effects of wastewater and combined sewer overflows on water quality in the Blue River Basin, Kansas City, Missouri and Kansas, July 1998-October 2000: U.S. Geological Survey Water-Resources Investigations Report 02-4107, 162 p. 


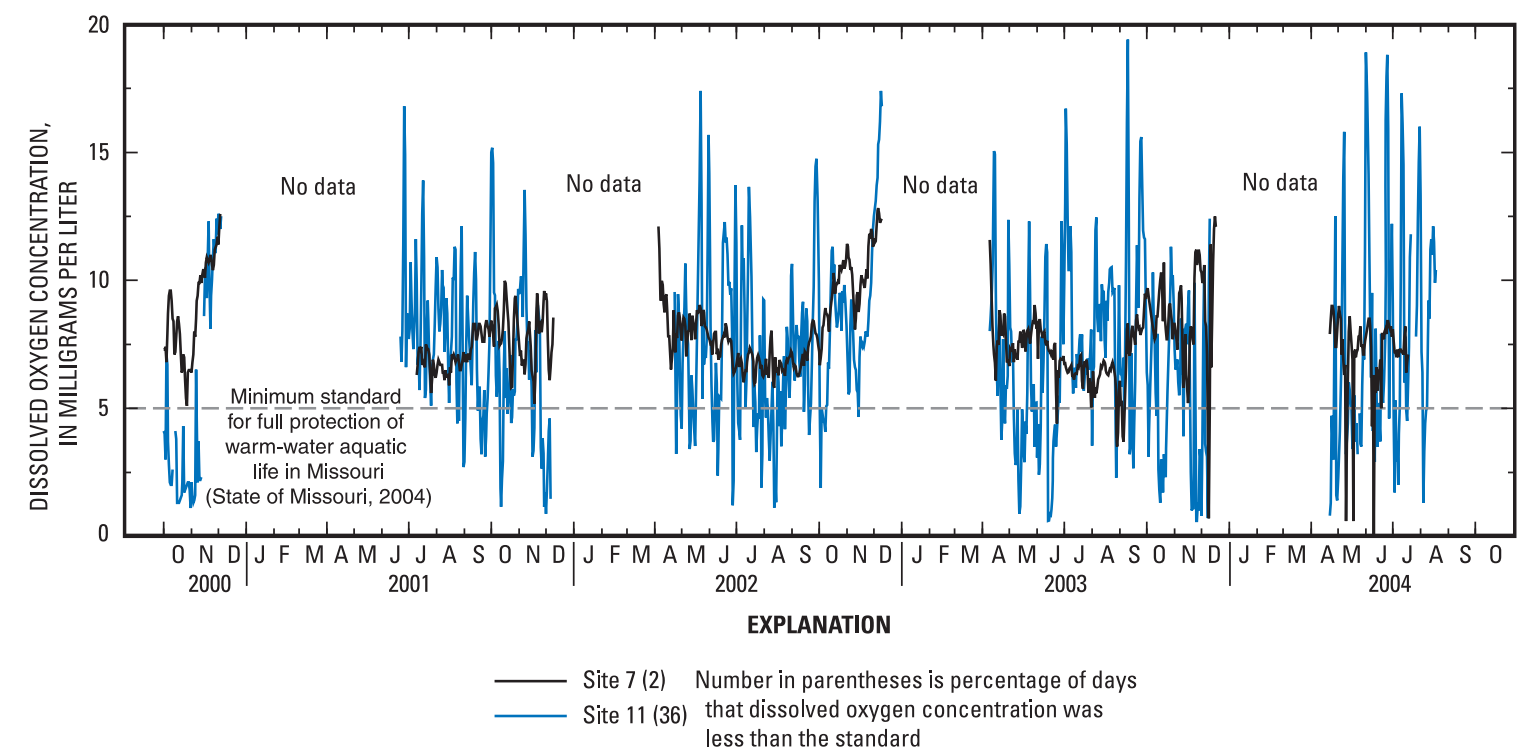

Figure 7. Time-series plots of mean daily dissolved oxygen concentration from October 2000 through 0ctober 2004.

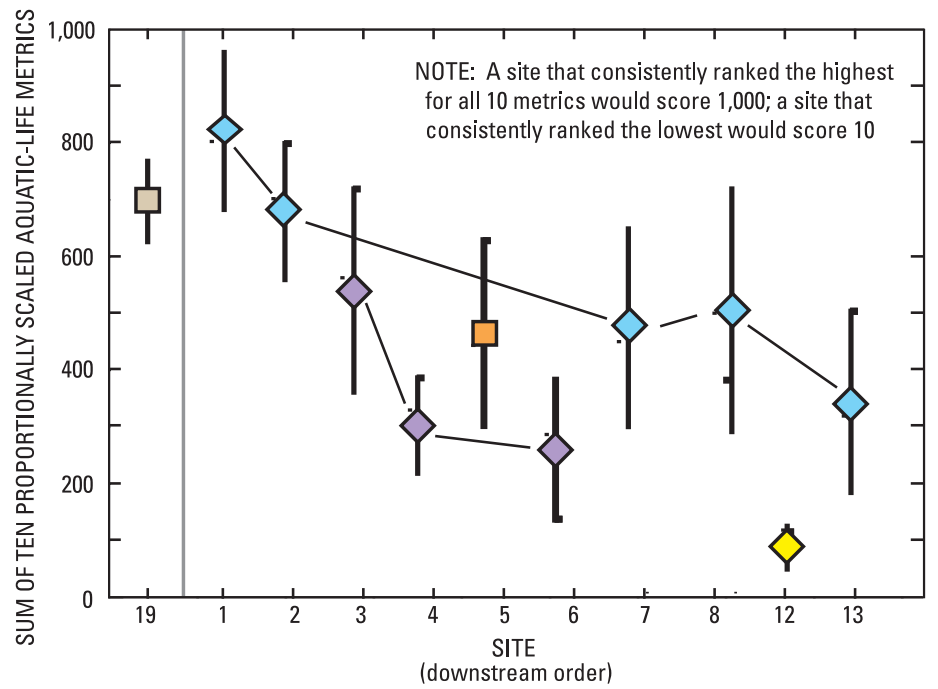

EXPLANATION

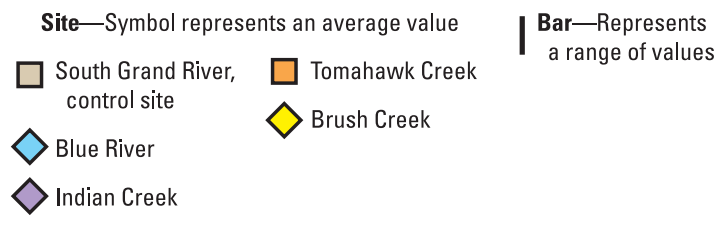

Figure 8. Sum of 10 proportionally scaled aquatic-life metrics by site.

Wilkison, D.H., Armstrong, D.J., Brown,

R.E., Poulton, B.C., Cahill, J.D., and

Zaugg, S.D., 2005, Water-quality and

biologic data for the Blue River Basin,

Kansas City metropolitan area, October
2000 to October 2004: U.S. Geological Survey Data-Series Report 127, 158 p.

Wilkison, D.H., Armstrong, D.J., Norman, R.D., Poulton, B.C., Furlong, E.T., and Zaugg, S.D., 2006, Water- quality in the Blue River Basin, Kansas City metropolitan area, July 1998 to October 2004: U.S. Geological Survey Scientific Investigations Report 06-5147, $170 \mathrm{p}$.

For more information contact any of the following:

For water information:

U.S. Geological Survey, Director 1400 Independence Road, Mail Stop 100 Rolla, Missouri 65401

(573) 308-3667 or "http://mo.water.usgs.gov".
For more information on all USGS reports and products (including maps, images, and computerized data), call 1-888-ASK-USGS.
Additional earth science information can be found by accessing the USGS "Home Page" on the Internet at "http://www.usgs.gov". 